\title{
Urea turnover and transfer to the digestive tract in the rabbit
}

\author{
BY S. J. FORSYTHE* AND D. S. PARKER \\ Department of Agricultural Biochemistry and Nutrition, University of \\ Newcastle upon Tyne, Newcastle upon Tyne NE1 $7 R U$
}

(Received 22 May 1984 - Accepted 17 August 1984)

\begin{abstract}
1. ${ }^{14} \mathrm{C}$ and ${ }^{15} \mathrm{~N}$ isotopes of urea were infused intravenously into rabbits for $6-8 \mathrm{~h}$ in order to measure urea synthesis and the extent of degradation in the digestive tract. The results indicate that 0.62 of the urea flux was excreted in the urine and that re-incorporation of urea- $\mathrm{N}$ following hydrolysis in the gut represented 0.3 of the urea synthesis rate.

2. Sampling of metabolites from the caecum by dialysis provided an opportunity to assess the contribution of urea-N to the caecal ammonia pool. This contribution is calculated to be 0.25 of caecal ammonia turnover.

3. Infusion of a urease $(E C 3.5 .1 .5)$ inhibitor during a continuous infusion of $\left[{ }^{14} \mathrm{C}\right]$ urea into the caecum permitted the measurement of urea turnover within the caecum.

4. Results obtained for urea entry into the caecum are contrasted with the measured urea degradation rate in the gut.
\end{abstract}

In the rabbit, as in other terrestial vertebrates, a significant proportion of endogenous urea is recycled to the digestive tract where it is hydrolysed by the bacterial microflora (Regoeczi et al. 1965). There is little evidence as to the site of entry of urea into the gut of the rabbit although urea is reported to enter the caecum by diffusion into the ileal contents (Loehry et al. 1973). The urea concentration of ileal contents, however, appears to be very variable, ranging from $0.2 \mathrm{mM}$ (Candau et al. 1980) to $7 \mathrm{mM}$ (Knutson et al. 1977). Arteriovenous differences for urea across the rabbit caecum have been reported as being negligible (Marty et al. 1976) although these studies were carried out on an isolated perfused preparation which may not reflect the situation in vivo.

Previous studies of urea kinetics in the rabbit (Regoeczi et al. 1965) have analysed a single pool (the blood) following tracer administration. In order to investigate the relation between urea kinetics and the transfer of urea to the digestive tract, it was decided to combine the continuous infusion of isotopes into the blood with a technique of sampling metabolites from the caecum of the conscious animal (Parker \& McMillan, 1976). Both ${ }^{14} \mathrm{C}$ and ${ }^{15} \mathrm{~N}$ isotopes of urea were used in the present study in order to allow for the calculation of urea synthesis rate, urea degradation rate and the re-utilization of ammonia for urea synthesis following resorption from the gut.

\section{MATERIALS AND METHODS}

Animals and surgery

New Zealand White and cross-bred Black and Brindle rabbits (2.4-3.5 kg body-weight) were purchased from a commercial source. They were maintained on a standard laboratory diet $(141 \mathrm{~g}$ crude protein $(\mathrm{CP} ; \mathrm{N} \times 6.25) / \mathrm{kg}, 155 \mathrm{~g}$ crude fibre $/ \mathrm{kg})$ which did not contain a coccidiostat. Feed and water were available at all times.

General anaesthesia was induced with a gas mixture of halothane (May and Baker, Dagenham, Essex) in oxygen (3:97, v/v) given through an open mask. All surgery was carried out under aseptic conditions. Implantation of the caecal probe was carried out as previously reported (Parker \& McMillan, 1976) and in addition catheters were placed in

* Present address: Department of Biochemistry, University of Birmingham, Birmingham B15 2TT. 
the carotid artery and the jugular vein (Jones \& Parker, 1978). Animals were eating normally within $4 \mathrm{~d}$ of the operation and infusion experiments were carried out over the following 10-14 d dependent on the integrity of the dialysis tubing surrounding the probe.

\section{Isotope infusion and sample collection}

$\left[{ }^{15} \mathrm{~N}\right] \mathrm{urea}$ was infused continuously into the jugular vein $(976 \mu \mathrm{g}$ urea-N/h, 75.8 atoms $\%$ excess) in sterile saline $(9 \mathrm{~g}$ sodium chloride/1) for periods of $7-10 \mathrm{~h}$. Separate infusions of $\left[{ }^{14} \mathrm{C}\right]$ urea into the jugular vein $(5 \cdot 0 \mu \mathrm{Ci} / \mathrm{h})$ were also carried out over similar time periods. The infusion rate was assessed by weighing the infusate during the experimental period. During this time the animals were lightly restrained in a Perspex metabolism box with feed and water available at all times. Samples of arterial blood $(1 \mathrm{ml})$ were withdrawn into a heparinized syringe from the carotid catheter at regular intervals. In addition, saline was pumped round the dialysis probe $(3 \mathrm{ml} / \mathrm{h})$ and dialysate collected continuously in 15 -min fractions using a fraction collector. Following the isotope infusions, rabbits were returned to their cages and urine collected for $48 \mathrm{~h}$. Separation of faeces and urine was achieved by stretching a nylon mesh ( $2 \mathrm{~mm}$ pore size) over the collecting tray which contained sulphuric acid $(10 \mathrm{ml}, 500 \mathrm{ml} / \mathrm{l})$ to preserve the urine and release urinary bicarbonate.

\section{Analytical methods}

Blood plasma and caecal dialysate were deproteinized by the method of Somogyi (1945) using barium hydroxide $(0.15 \mathrm{~mm})$ and zinc sulphate $(0.3 \mathrm{~mm})$. This method has the advantage of removing labelled bicarbonate from plasma which would interfere with the determination of $\left[{ }^{14} \mathrm{C}\right]$ urea specific activity. Urea concentration in deproteinized plasma and caecal dialysate was determined by the diacetyl monoxime reaction (Moore \& Kaufmann, 1970). The specific activity of $\left[{ }^{14} \mathrm{C}\right]$ urea in plasma was calculated from the urea concentration and the radioactivity determined on a portion $(500 \mu \mathrm{l})$ of supernatant material dissolved in $10 \mathrm{ml}$ scintillant (Ready Solv-E P; Beckman RIIC, England) and counted in a liquid-scintillation counter. All counts were corrected for quench and expressed as disintegrations/min. The ammonia concentration was determined by the method of Weatherburn (1967). Acetohydroxamic acid was determined by the method of Fishbein et al. (1965). Samples for the measurement of ${ }^{15} \mathrm{~N}$ label in urea or ammonia were pretreated using a modification of the Conway microdiffusion method. Urea- $\mathbf{N}$ was measured by treatment with urease $(E C 3.5 .1 .5 ; 2 \mathrm{mg} / \mathrm{ml}$ in $100 \mathrm{ml}$ glycerol/l) for $1 \mathrm{~h}$ in the outer well of the unit and the ammonia evolved by the addition of saturated potassium carbonate was trapped in hydrochloric acid $(6.66 \mathrm{~mm})$ in the centre well. Ammonia was liberated from caecal dialysate by the addition of saturated potassium carbonate and trapped as before. Ammonia concentration was determined in a portion of the solution (Weatherburn, 1967) and the remaining part evaporated to dryness before ${ }^{15} \mathrm{~N}$ analysis. ${ }^{15} \mathrm{~N}$ analysis was carried out by optical emission spectrometry using the method of Goulden \& Salter (1979). Samples of $\left[{ }^{5} \mathrm{~N}\right]$ ammonium chloride were diluted immediately before analysis to enrichments of less than 8 atoms $\%$ excess and a $\mathrm{N}$ content of about $2 \mu \mathrm{g} \mathrm{N} / \mu \mathrm{l}$. Triplicate injections of $5 \mu \mathrm{l}$ were made for each sample and background abundance of the tracer determined by analysis of samples taken before the administration of the $\left[{ }^{15} \mathrm{~N}\right]$ urea.

\section{Mathematical analysis of isotope values}

Values from the continuous-infusion experiments were analysed using the methods described by Cocimano \& Leng (1967) and Nolan \& Leng (1974). Plasma ${ }^{14} \mathrm{C}$ specific radioactivity and ${ }^{15} \mathrm{~N}$-enrichment time-curves did not come to a plateau during the course of the experiment $(7-10 \mathrm{~h})$ and were analysed using the Maximum Likelihood Program (MLP, version 3.07, 1980; Rothamsted Experimental Research Station, Harpenden, Herts) to predict the plateau specific radioactivity and enrichment values. 
Table 1. Plasma urea-carbon irreversible loss rate (ILR), proportion of infused dose excreted in the urine and urea degradation rate in rabbits continuously infused with $\left[{ }^{14} \mathrm{C}\right]$ urea $(5 \mu \mathrm{Ci} / \mathrm{h})$

(Standard errors for values of individual ILR determinations in parentheses)

\begin{tabular}{|c|c|c|c|}
\hline Rabbit & $\begin{array}{l}\text { Plasma urea-C ILR } \\
(\mathrm{mg} \text { urea-C/h) }\end{array}$ & $\begin{array}{l}\text { Proportion of dose } \\
\text { excreted in urine }\end{array}$ & $\begin{array}{c}\text { Urea degradation } \\
\text { rate } \\
(\mathrm{mg} \text { urea-C/h) }\end{array}$ \\
\hline NT26 & $25 \cdot 2(1 \cdot 18)$ & 0.52 & $14 \cdot 7$ \\
\hline NT27 & $28.0(1.50)$ & 0.59 & $11 \cdot 9$ \\
\hline NT29 & $15 \cdot 1(1 \cdot 58)$ & 0.68 & $9 \cdot 1$ \\
\hline NT31 & $28.6(4.40)$ & 0.61 & $12 \cdot 4$ \\
\hline NT33 & $31.4(1.35)$ & 0.70 & $18 \cdot 5$ \\
\hline NT37 & $30 \cdot 1(3 \cdot 60)$ & - & - \\
\hline NT39 & $25.9(2.40)$ & 0.60 & $8 \cdot 7$ \\
\hline Mean & $26 \cdot 3$ & 0.62 & $12 \cdot 6$ \\
\hline SE & $2 \cdot 0$ & 0.03 & $1 \cdot 5$ \\
\hline
\end{tabular}

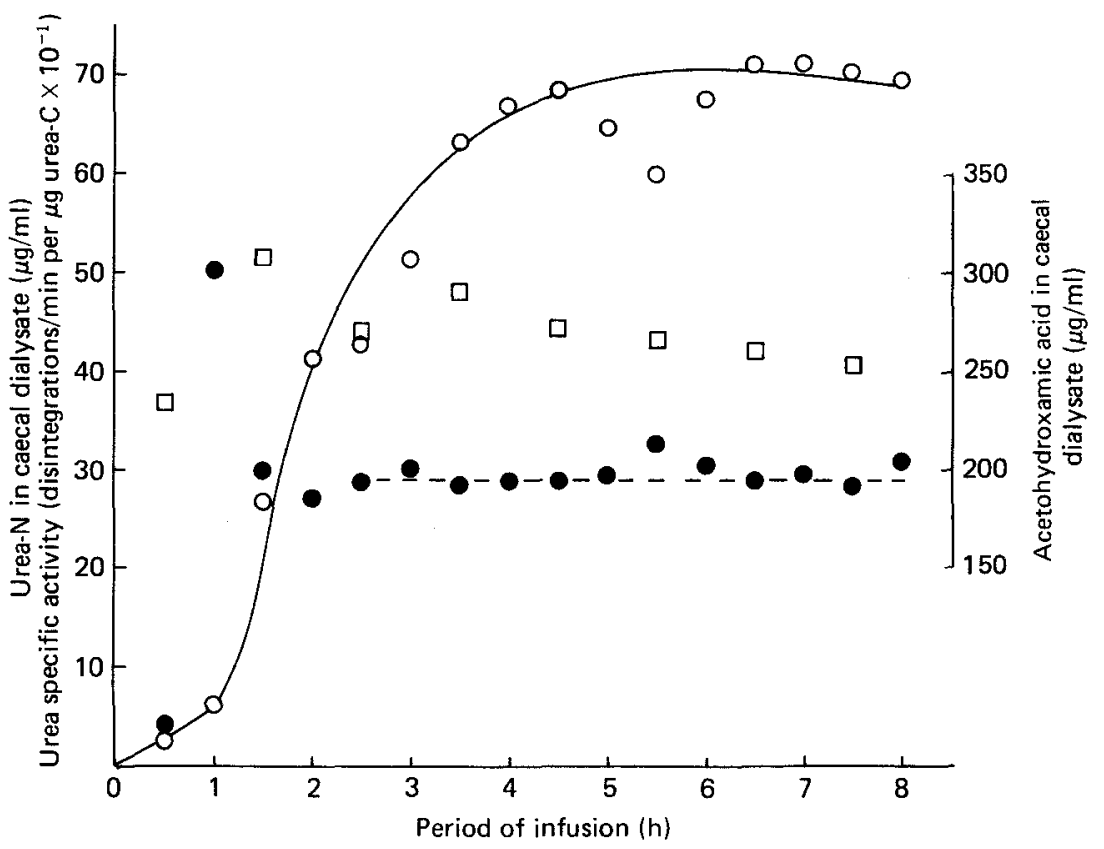

Fig. 1. Concentration of urea-nitrogen $(\mu \mathrm{g} / \mathrm{ml}, \mathrm{O})$, urea specific radioactivity (disintegrations $/ \mathrm{min}$ per $\mu \mathrm{g}$ urea-carbon, $O)$ and concentration of acetohydroxamic acid $(\mu \mathrm{g} / \mathrm{ml}, \square)$ in caecal dialysate during continuous infusion of ${ }^{19} \mathrm{C}$-urea $(0.6 \mu \mathrm{Ci} / \mathrm{h})$ and acetohydroxamic acid $(80 \mathrm{mg} / \mathrm{h})$ into the caecum of a rabbit. Plateau specific radioactivity was calculated as the mean of values between 3 and $10 \mathrm{~h}$ after the start of the infusion. Urea plateau specific radioactivity 292 (SE 4-79) disintegrations/min per $\mu$ g urea-C.

\section{RESULTS}

During isotope infusions, plasma urea concentrations and caecal probe dialysate ammonia concentrations remained constant $(0.35 \mathrm{mM})$, indicating that the animals were in metabolic steady-state. Plasma urea-C irreversible loss rate (ILR) was determined in seven rabbits from the known infusion rate of $\left[{ }^{14} \mathrm{C}\right]$ urea and the predicted plateau specific radioactivity value (Table 1). Mean plasma urea-C ILR was $26 \cdot 3$ (SE 2.0) $\mathrm{mg}$ urea-C/h and was assumed to 


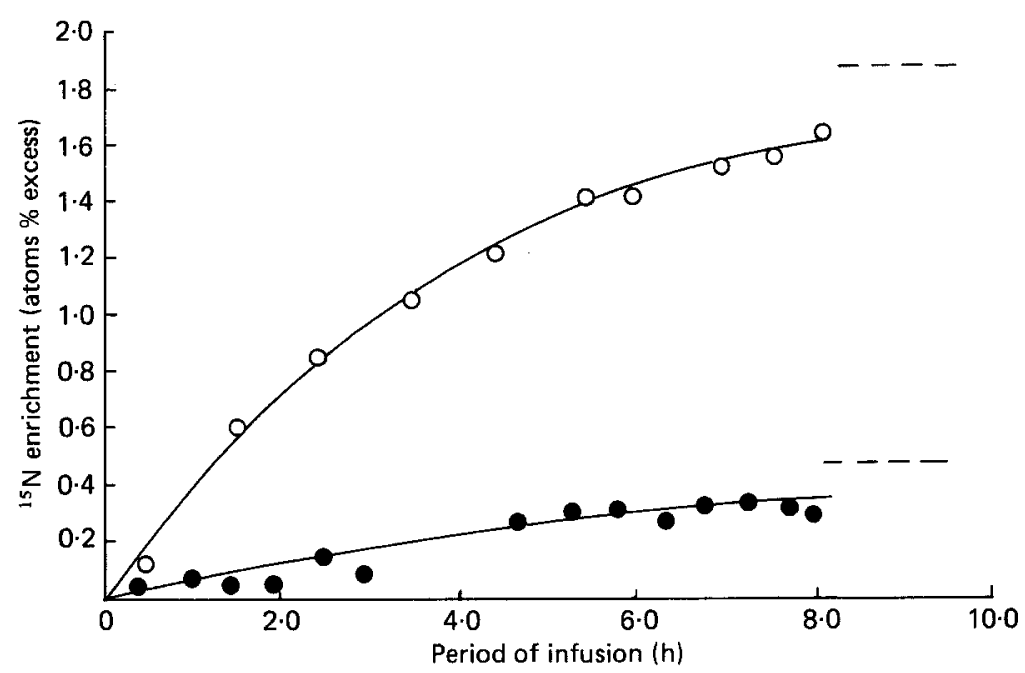

Fig. 2. Time course of ${ }^{15} \mathrm{~N}$ enrichment (atoms \% excess) of plasma urea-nitrogen $(\mathrm{O})$, and caecal dialysate ammonia-N $(\bullet)$ during intravenous infusion of $\left[{ }^{15} \mathrm{~N}\right]$ urea $(976 \mu \mathrm{g} \mathrm{N} / \mathrm{h})$ in a rabbit.

(--) Plateau enrichment value determined from analysis of curve as a single exponential fitted to the equation

$$
Y=A+B e^{-K t}
$$

where, for plasma urea-N, $A$ is 1.84 (SE 0.068 ), $B$ is -1.90 (SE 0.054 ) and $K$ is 0.257 (SE 0.025 ) and, for caecal dialysate ammonia-N, $A$ is 0.480 (SE 0.241 ), $B$ is -0.527 (SE 0.204 ) and $K$ is 0.158 (SE 0.130 ); $t$ is time.

be a measure of urea synthesis rate since the specific activity $v$. time curve was a single exponential indicating little urea-C recycling during the sampling period. ${ }^{14} \mathrm{CO}_{2}$ derived from urea hydrolysis in the gut would be expected to enter the body bicarbonate pool and be unlikely to enter the urea-C pool during the time-course of the experiment. Mean urea synthesis was calculated as 131.5 (SE 10.0$) \mathrm{mg}$ urea/h . The proportion of ${ }^{14} \mathrm{C}$ dose excreted in the urine $(0.62$, Table 1$)$ indicated that a significant proportion of urea flux did not enter this metabolic pool and is assumed to pass into the digestive tract. Calculation of urea degradation rate from a knowledge of urea synthesis rate and urea excretion rate into urine (Table 1) indicated that $63 \mathrm{mg}$ urea/h, equivalent to 0.48 of the urea synthesis rate, was degraded in the gastrointestinal tract.

Urea was not detectable in the caecal dialysate collected during intravenous infusion of either $\left[{ }^{14} \mathrm{C}\right]$ - or $\left[{ }^{15} \mathrm{~N}\right]$ urea. In order to obtain some information concerning urea entry into the caecum, three animals were infused intracaecally with acetohydroxamic acid $(150 \mathrm{mg}$ then $80 \mathrm{mg} / \mathrm{h})$, a non-competitive inhibitor of urease, together with $\left[{ }^{14} \mathrm{C}\right]$ urea $(0.6 \mu \mathrm{Ci} / \mathrm{h})$. Figure 1 shows the concentration of urea-N and acetohydroxamic acid in caecal dialysate collected during the infusion period. Plateau urea specific radioactivity was calculated as the mean of samples collected between 3 and $8 \mathrm{~h}$ after the start of the infusion. Mean urea ILR in the caecum calculated from these experiments was 16.8 (SE 2.3) $\mathrm{mg}$ urea/h. Plasma urea-N ILR was determined in nine rabbits following continuous infusion of $\left[{ }^{15} \mathrm{~N}\right]$ urea intravenously. Secondary labelling of the caecal ammonia-N pool was apparent within $1 \mathrm{~h}$ of isotope infusion (Fig. 2). Mean plasma urea-N ILR was $40 \cdot 2$ (SE 4.6) $\mathrm{mg}$ urea-N/h and comparison of plateau enrichment of $\mathrm{N}$ in the caecal ammonia pool with plasma urea values indicated that the proportion of caecal ammonia that was derived from plasma urea- $\mathrm{N}$ was 0.25 (Table 2). The rate at which urea- $\mathrm{N}$ was re-incorporated into urea following 
Table 2. Plasma urea-nitrogen irreversible loss rate (ILR), proportion of caecal ammonia derived from plasma urea and urea- $N$ re-utilization rate in rabbits continuously infused with $\left[{ }^{15} \mathrm{~N}\right]$ urea $(976 \mu \mathrm{g} \mathrm{N} / \mathrm{h})$

(Standard errors for values of individual ILR determinations in parentheses)

\begin{tabular}{|c|c|c|c|}
\hline Rabbit & $\begin{array}{l}\text { Plasma urea-N ILR } \\
(\mathrm{mg} \mathrm{N} / \mathrm{h})\end{array}$ & $\begin{array}{l}\text { Proportion of } \\
\text { caecal } \mathrm{NH}_{3} \\
\text { derived from } \\
\text { rumen urea }\end{array}$ & $\begin{array}{c}\text { Urea-N } \\
\text { re-utilization } \\
\text { rate }(\mathrm{mg} \mathrm{N} / \mathrm{h})\end{array}$ \\
\hline NT21 & $21.9(1 \cdot 19)$ & 0.27 & - \\
\hline NT26 & $43 \cdot 2(1 \cdot 60)$ & 0.25 & $15 \cdot 6$ \\
\hline NT27 & $57 \cdot 1(2 \cdot 47)$ & $0 \cdot 26$ & $8 \cdot 2$ \\
\hline NT29 & $20.7(5.90)$ & $0 \cdot 10$ & 14.5 \\
\hline NT31 & $56.1(4.45)$ & 0.44 & $10 \cdot 6$ \\
\hline NT33 & $54 \cdot 3(4 \cdot 70)$ & $0 \cdot 20$ & 19.0 \\
\hline NT37 & $35.5(6 \cdot 14)$ & $0 \cdot 18$ & 33.7 \\
\hline NT39 & $32 \cdot 0(2 \cdot 14)$ & - & $28 \cdot 4$ \\
\hline NT40 & $40 \cdot 1(4 \cdot 04)$ & 0.26 & - \\
\hline Mean & $40 \cdot 2$ & $0 \cdot 25$ & $18 \cdot 6$ \\
\hline SE & 4.6 & 0.03 & 3.5 \\
\hline
\end{tabular}

degradation in the gut was determined from urea- $\mathrm{N}$ synthesis rate (urea synthesis rate from ${ }^{14} \mathrm{C}$ infusion $\times 28 / 60$ ) and urea-N ILR. The mean rate of urea-N re-utilization was $18 \cdot 6$ (SE 3.5 ) $\mathrm{mg} \mathrm{N} / \mathrm{h}$ which was equivalent to 0.30 of the urea-N synthesis rate (Table 2).

\section{DISCUSSION}

Urea kinetics in the plasma of rabbits determined using continuous infusions of ${ }^{14} \mathrm{C}$ and ${ }^{15} \mathrm{~N}$ isotopes may be compared with results obtained from single-shot isotope administration. In both cases the values obtained for C and N ILR in the present experiments, i.e. $24 \mathrm{mg}$ urea-C/h and $40 \cdot 2 \mathrm{mg}$ urea-N/h, were lower than those reported by Regoeczi et al. (1965) $(36 \mathrm{mg}$ urea-C/h and $65 \mathrm{mg}$ urea-N/h). It is unlikely that the method of isotope administration would explain this difference. The difference may arise from variation in dietary intake of $\mathrm{N}$ but no details of the diet used by Regoeczi et al. (1965) are available. The urea-N ILR will include a measure of urea-N recycling from the digestive tract, although this is not apparent in the enrichment curve which was analysed as a single exponential rather than as two exponentials. In agreement with the results derived from the single injection of ${ }^{15} \mathrm{~N}$ (Regoeczi et al. 1965), it proved impossible to separate the recycling component of the $\mathrm{N}$ flux in analysis of the values obtained for urea-N enrichment in the plasma.

The difference in plasma urea ILR calculated using ${ }^{14} \mathrm{C}$ and ${ }^{15} \mathrm{~N}$ tracer values, 131.5 and $89 \mathrm{mg}$ urea/h respectively, is a measure of the re-utilization of urea-N in hepatic synthesis of urea. In the present study, re-utilization of urea- $\mathrm{N}$ by the tissues of the rabbit represented 0.30 of the urea synthesis rate compared with 0.21 reported by Regoeczi et al. (1965). In man, values of 0.15 and 0.7 have been reported for urea- $\mathrm{N}$ re-utilization (Walser \& Bodenlos, 1959; Long et al. 1978) whereas in the rock hyrax (Procaria habessinica) re-incorporation of urea-N was 0.25 of the urea synthesis rate on an $82 \mathrm{~g} \mathrm{CP} / \mathrm{kg}$ diet and decreased to 0.02 on restricting water intake to $60 \%$ of ad lib. intake (Hume et al. 1980). In studies with sheep, urea-N re-utilization was 0.18 of urea synthesis rate on a low- 
Table 3. Entry rate of urea ( $\mathrm{mg}$ urea/h) into the digestive tract of rabbits

(Values in parentheses indicate the number of animals used in each calculation)

\begin{tabular}{|c|c|c|c|c|}
\hline & \multicolumn{2}{|c|}{$\begin{array}{l}\text { Urea degradation } \\
\text { rate }\end{array}$} & \multirow{2}{*}{$\begin{array}{l}\text { Urea entry } \\
\text { rate into } \\
\text { caecal } \\
\text { lumen } \ddagger\end{array}$} & \multirow{2}{*}{$\begin{array}{l}\text { Caecal urea } \\
\text { ILR\& }\end{array}$} \\
\hline & $*$ & $\dagger$ & & \\
\hline $\begin{array}{l}\text { Mean } \\
\mathrm{SE}\end{array}$ & $\begin{array}{c}63.0 \\
7.5 \\
(6)\end{array}$ & $\begin{array}{c}60.6 \\
11 \cdot 3 \\
(6)\end{array}$ & $\begin{array}{c}12 \cdot 8 \\
2 \cdot 3 \\
(7)\end{array}$ & $\begin{array}{c}16.8 \\
2 \cdot 4 \\
(3)\end{array}$ \\
\hline
\end{tabular}

ILR, irreversible loss rate.

* Difference between urea synthesis rate and urea excretion rate.

$\dagger$ Calculated from urea excretion rate and proportion of ${ }^{14} \mathrm{C}$ dose excreted in the urine.

$\ddagger$ ILR of caecal ammonia-nitrogen $\times$ the proportion of caecal ammonia-N derived from plasma urea-N.

$\S$ Calculated from caecal $\left[{ }^{14} \mathrm{C}\right]$ urea/acetohydroxamic acid infusion experiment.

quality-roughage diet (Nolan \& Stachiw, 1979) whereas on a lucerne (Medicago sativa) chaff diet the proportion was 0.11 (Nolan \& Leng, 1972; Nolan et al. 1976). The present results suggest that the non-ruminant herbivores show a higher rate of urea- $\mathrm{N}$ re-utilization than do the ruminant species, although the influence of dietary manipulation on this recycling requires further investigation.

The entry of urea into the digestive tract may be calculated by a number of methods and the results obtained are summarized in Table 3 . The rate at which urea was degraded in the whole tract was determined as either the difference between urea synthesis rate and urea excretion rate or from the urinary urea excretion rate and the proportion of the ${ }^{14} \mathrm{C}$ dose excreted in the urine. The mean value for the two methods $(61.8 \mathrm{mg} \mathrm{urea} / \mathrm{h})$ is very similar to that determined by Regoeczi et al. (1965) of $67 \mathrm{mg}$ urea/h and represents 0.48 of the urea synthesis rate. In sheep, urea degradation rate ranged from 0.38 to 0.76 of the urea synthesis rate (Nolan \& Leng, 1972; Nolan et al. 1976; Nolan \& Stachiw, 1979; Norton et al. 1982) and was reported as 0.55 for cattle on a hay-based diet (Kennedy, 1980). In non-ruminant species, values for the rock hyrax (Hume et al. 1980) and the horse (Prior et al. 1974) indicate that urea degradation rates are equivalent to 0.61 and 0.66 respectively of the urea synthesis rate whereas, in non-herbivorous species, lower values have been obtained (pig 0.25 (Thacker et al. 1982) man 0.29 (Gibson et al. 1976)).

In view of the caecum being the major site of urease activity within the rabbit gut (Forsythe, 1983), it was of interest to assess the transfer of urea from blood into this section of the gastrointestinal tract. The rate of plasma urea entry into the caecum was determined from a knowledge of the proportion of caecal ammonia- $\mathrm{N}$ derived from plasma urea (Table 2) and the rate of caecal ammonia-N ILR (Forsythe et al. 1982). Plasma urea entry into the caecum was calculated at $12.8 \mathrm{mg}$ urea/h (Table 3 ) or about one-quarter of the urea degradation rate. On a metabolic body-weight basis the plasma urea entry into the caecum of the rabbit was $6 \mathrm{mg}$ urea $/ \mathrm{h}$ per $\mathrm{kg}$ body-weight ${ }^{0.75}$, which was similar to the values of 8 and $9 \mathrm{mg}$ urea $/ \mathrm{h}$ per kg body-weight ${ }^{0} \cdot 75$ determined as the entry rates of urea in the rumen and caecal ammonia pools in sheep (Nolan et al. 1976). The values derived in the present study from the infusion of $\left[{ }^{14} \mathrm{C}\right]$ urea and acetohydroxamic acid into the caecum (Table 3) provide another measure of urea flux in this portion of the digestive tract. The infusion of the urease inhibitor resulted in a rapid rise in urea concentration in dialysate (Fig. 1) and allowed for the sampling of $\left[{ }^{14} \mathrm{C}\right]$ urea which was the basis for calculation of caecal urea ILR. This was achieved in three animals and the mean value of $16.8 \mathrm{mg}$ urea/h could be 
assumed to equal the rate of plasma urea entry into the caecum if all caecal urea were derived from the plasma. This value is comparable with that derived from ${ }^{15} \mathrm{~N}$ studies but represents only 0.25 of the calculated urea degradation rate. Urea movement into the caecum as determined by ${ }^{15} \mathrm{~N}$ in our study was dependent on rapid mixing of the ammonia- $\mathrm{N}$ resulting from urea hydrolysis with the caecal ammonia pool. It is possible, however, that urea entering across the mucosa may be hydrolysed at the mucosal surface and a proportion of the released ammonia re-absorbed into the portal vein without mixing with the sampled caecal ammonia pool (Wrong \& Vince, 1984). Similarly, with the $\left[{ }^{14} \mathrm{C}\right]$ urea and acetohydroxamic acid infusions, errors may have been introduced as a result of the inhibition of bacterial urease, particularly if the activity associated with bacteria adherent to the mucosa is important in the regulation of urea transfer as has been suggested for the rumen (Cheng \& Wallace, 1979).

Entry of urea into the caecum as a component of ileal digesta can be calculated from the urea concentration of ileal contents ( $66 \mu \mathrm{g}$ urea $/ \mathrm{ml}$ in the present study) and ileal flow-rate (20 ml/h, A. G. Stephens personal communication). This calculation indicates that $1.3 \mathrm{mg}$ urea $/ \mathrm{h}$ enters the caecum as a component of ileal digesta, although this value would increase to $9.6 \mathrm{mg}$ urea $/ \mathrm{h}$ if the ileal concentration of $480 \mu \mathrm{g} / \mathrm{ml}$ reported by Knutson $e t$ al. (1977) were used. This higher value represents 0.14 of the urea degradation rate and $0.6-0.8$ of the urea ILR determined in the caecum using $\left[{ }^{14} \mathrm{C}\right]$ urea and acetohydroxamic acid. Only 0.15 of urea degradation rate in man could be attributed to urea entering the large intestine with ileal digesta (Wrong et al. 1981) indicating that, if the large intestine is the major site of urease activity and therefore urea hydrolysis, a major portion of the measured urea movement into the gut is likely to be into this part of the intestine.

In the rabbit, degradation of urea in the digestive tract represents a significant pathway of urea disposal from the blood. Although it has been possible to demonstrate transfer of urea into the caecum and the re-utilization of urea- $\mathrm{N}$ produced in the gastrointestinal tract for urea synthesis, the proportion of urea apparently entering the caecum from the blood was only 0.25 of the urea degradation rate. Since only 0.14 of the urea degraded could be accounted for by ileal flow into the large intestine it is suggested that urea entry into the caecum from the plasma represents the major site of urea hydrolysis and that the methodology applied to quantify this movement may not have been sufficiently sensitive to provide confirmation of this.

The authors are grateful to Dr D. N. Salter at the National Institute for Research in Dairying for allowing access to the emission spectrometer for ${ }^{15} \mathrm{~N}$ analysis and to $\mathrm{Mr} \mathrm{I}$. Montgomery for his technical assistance. This work was supported by the SERC.

\section{REFERENCES}

Candau, M., Fioramonti, J. \& Touitou, M. (1980). In Proceedings of the Second World Rabbit Congress, pp. 81-89. Barcelona, Spain: Association Espanola de Cunicultura.

Cheng, K.-J. \& Wallace, R. J. (1979). British Journal of Nutrition 42, 553-557.

Cocimano, M. R. \& Leng, R. A. (1967). British Journal of Nutrition 21, 353-371.

Fishbein, W. N., Winter, R. S. \& Davidson, J. D. (1965). Journal of Biological Chemistry 240, 2402-2406.

Forsythe, S. J. (1983). Ammonia metabolism in the caecum of the rabbit. PhD Thesis, University of Newcastle upon Tyne.

Forsythe, S. J., Parker, D. S., Montgomery, I. \& Salter, D. N. (1982). In Proceedings of the IV International Symposium on Protein Metabolism and Nutrition, pp. 347-350. EAAP Publication no. 31.

Gibson, J. A., Park, N. J., Sladen, G. E. \& Dawson, A. M. (1976). Clinical Science and Molecular Medicine 50, $51-59$.

Goulden, J. D. S. \& Salter, D. N. (1979). Analyst (London) 104, 756-765.

Hume, I. D., Rubsamen, K. \& Englehart, W. (1980). Journal of Comparative Physiology 138, 307-314.

Jones, C. S. \& Parker, D. S. (1978). Biochemical Journal 174, 291-296. 
Kennedy, P. M. (1980). British Journal of Nutrition 43, 125-140.

Knutson, R. S., Francis, R. S., Hall, J. K., Moore, B. H. \& Heisinger, J. F. (1977). Comparative Biochemistry and Physiology 58A, 151-154.

Loehry, C. A., Kingham, J. \& Baker, J. (1973). Gut 14, 683-688.

Long, C. L., Keevanandam, M. \& Kinney, J. M. (1978). American Journal of Clinical Nutrition 31, $1367-1382$.

Marty, J., Lavarde, M. A. \& Raynaud, P. (1976). Annales de Biologie Animale, Biochimie et Biophysique 16, 85-95.

Moore, R. B. \& Kaufmann, N. J. (1970). Analytical Biochemistry 33, 263-272.

Nolan, J. V. \& Leng, R. A. (1972), British Journal of Nutrition 27, 177-194.

Nolan, J. V. \& Leng, R. A. (1974). Proceedings of the Nutrition Society 33, 1-8.

Nolan, J. V., Norton, B. W. \& Leng, R. A. (1976). British Journal of Nutrition 35, 127-147.

Nolan, J. V. \& Stachiw, S. (1979). British Journal of Nutrition 42, 63-80.

Norton, B. W., Mackintosh, J. B. \& Armstrong, D. A. (1982). British Journal of Nutrition 48, $249-264$.

Parker, D. S. \& McMillan, R. T. (1976). British Journal of Nutrition 35, 365-371.

Prior, R. K., Hintz, H. F., Lowe, J. E. \& Visek, W. J. (1974). Journal of Animal Science 38, 565-571.

Regoeczi, E., Irons Koj, A. \& McFarlane, A. S. (1965). Biochemical Journal 95, 521-532.

Somogyi, M. (1945). Journal of Biological Chemistry 16, 69-73.

Thacker, P. A., Bowland, J. P., Milligan, L. P. \& Weltzein, F. (1982). Canadian Journal of Animal Science 62, 1193-1197.

Walser, M. \& Bodenlos, L. J. (1959). Journal of Clinical Investigation 38, 1617-1626.

Weatherburn, M. W. (1967). Analytical Chemistry 39, 971-974.

Wrong, O. M., Edmonds, C. J. \& Chadwick, V. S. (1981). The Large Intestine: Its Role in Mammalian Nutrition and Homeostasis. Lancaster: MTP Press.

Wrong, O. M. \& Vince, A. (1984). Proceedings of the Nutrition Society 43, 77-86. 